
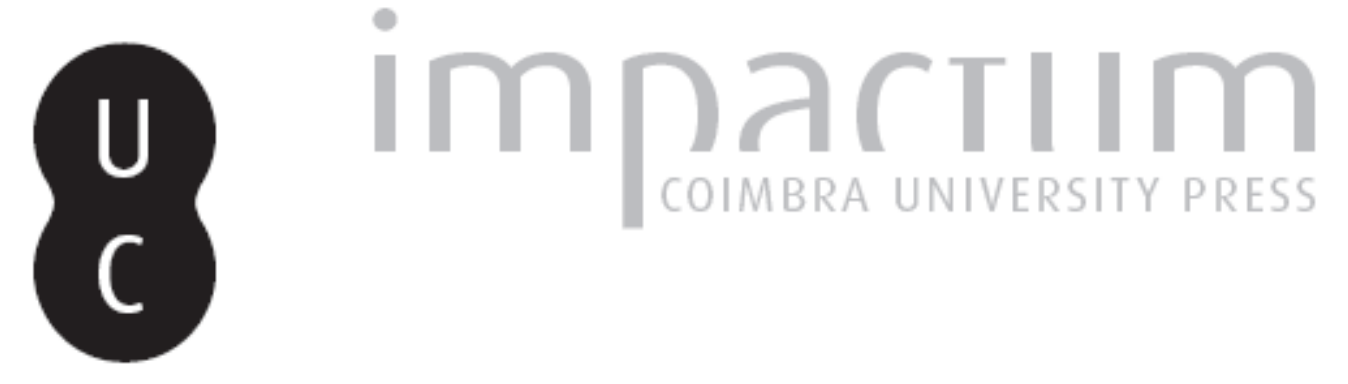

\title{
Elenchus, Recollection, and the Method of Hypothesis in the Meno
}

Autor(es): lonescu, Cristina

Publicado por: Imprensa da Universidade de Coimbra

URL persistente:

URI:http://hdl.handle.net/10316.2/43593

DOI: $\quad$ DOI:https://doi.org/10.14195/2183-4105_17_1

Accessed : $\quad$ 26-Apr-2023 13:56:19

A navegação consulta e descarregamento dos títulos inseridos nas Bibliotecas Digitais UC Digitalis, UC Pombalina e UC Impactum, pressupõem a aceitação plena e sem reservas dos Termos e Condições de Uso destas Bibliotecas Digitais, disponíveis em https://digitalis.uc.pt/pt-pt/termos.

Conforme exposto nos referidos Termos e Condições de Uso, o descarregamento de títulos de acesso restrito requer uma licença válida de autorização devendo o utilizador aceder ao(s) documento(s) a partir de um endereço de IP da instituição detentora da supramencionada licença.

Ao utilizador é apenas permitido o descarregamento para uso pessoal, pelo que o emprego do(s) título(s) descarregado(s) para outro fim, designadamente comercial, carece de autorização do respetivo autor ou editor da obra.

Na medida em que todas as obras da UC Digitalis se encontram protegidas pelo Código do Direito de Autor e Direitos Conexos e demais legislação aplicável, toda a cópia, parcial ou total, deste documento, nos casos em que é legalmente admitida, deverá conter ou fazer-se acompanhar por este aviso.

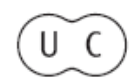


ISSN 2079-7567 eISSN 2183-4105

0

\section{Established 1989}

http://platosociety.org/

\section{Papers}

Cristina lonescu Elenchus, Recollection, and the Method of Hypothesis in the Meno

Lucas Soares

La relectura positiva de la tradición poética griega en el Banquete de Platón

Etienne Helmer Le commerce de la vérité: économie et commerce dans les Lois de Platon

Alan Pichanick

Socratic Silence in the Cleitophon

Thanassis Gkatzaras The Form of the Good in Plato's Timaeus

James M. Ambury Dialectical Epimeleia:

Platonic Care of the Soul and Philosophical Cognition
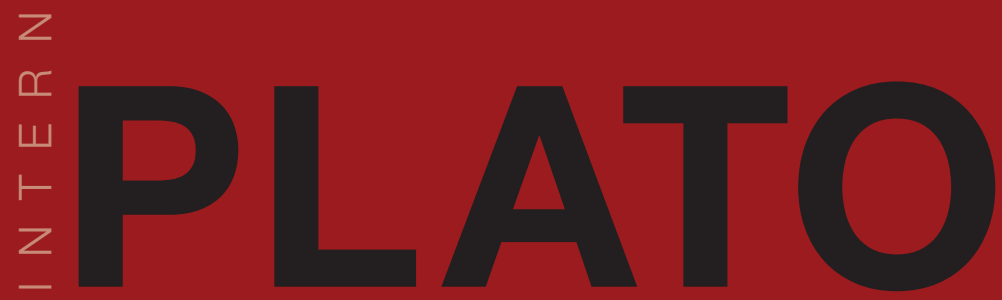

Book Reviews

Nicholas Zucchetti

Essays on Plato's Epistemology by Franco Trabattoni

Alan Pichanick

Socrates and Self-Knowledge by Christopher Moore
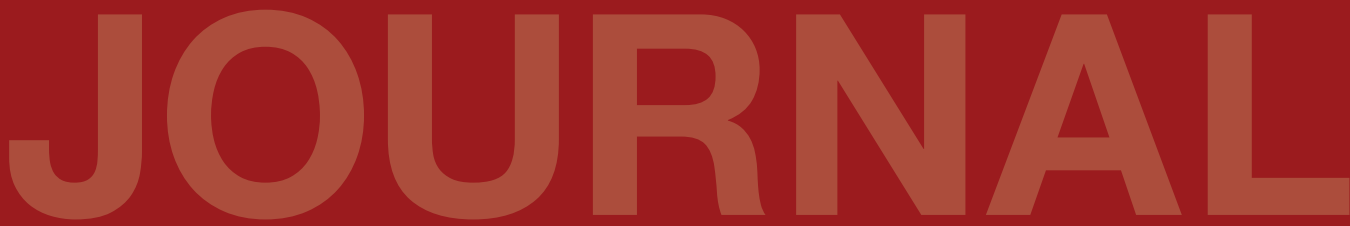

Société Platonicienne Internationale

Associazione Internazionale dei Platonisti

Sociedad Internacional de Platonistas

Internationale

Platon-Gesellschaft

Imprensa da

Universidade

de Coimbra

Coimbra

Universiy

Press 


\section{Elenchus, Recollection, and the Method of Hypothesis in the Meno}

\section{Cristina lonescu}

The Catholic University of America

ionescu@cua.edu

\section{ABSTRACT}

The Meno is often interpreted as an illustration of Plato's decision to replace elenchus with recollection and the method of hypothesis. My paper challenges this view and defends instead two theses: (1) that far from replacing elenchus, the method of hypothesis incorporates and uses elenctic arguments in order to test and build its own steps; and (2) that recollection is not a method of search on a par with elenchus and the method of hypothesis, but is rather primarily a theory that accounts for the metaphysical horizon within which the method of hypothesis, coupled with elenchus and perhaps other dialectical methods, can lead us from opinions to knowledge.

Keywords: Elenchus, Method of Hypothesis, Recollection
The Meno is often taken to showcase Plato's decision to replace elenchus with recollection and the method of hypothesis. The purpose of the present paper is to challenge this reading and to advance, instead, a different understanding of the relations among elenchus, recollection, and the method of hypothesis in the Meno. In particular, I am going to defend two theses: (1) that far from replacing elenchus, the method of hypothesis incorporates and uses elenctic arguments in order to test and build its own steps; and (2) that recollection is not a method of search on a par with elenchus and the method of hypothesis, but is rather primarily a theory that accounts for the metaphysical horizon within which the method of hypothesis, coupled with elenchus and perhaps other dialectical methods, can lead us from opinions to knowledge.

In recent literature, Landry (2012) and Benson $(2003,2015)$ come closest to defending a similar view, as they both argue that elenchus is not replaced by the method of hypothesis, but rather supplemented by it. My own view differs in some respects from theirs, and where it is consistent with theirs, it takes their findings a step further. More specifically, Landry argues that the method of hypothesis is to be applied only once elenchus has finished cleansing the mind of inconsistent beliefs, and that the method of hypothesis proceeds alone and unaided by elenchus to seek knowledge. I argue that elenchus is used not only before the method of hypothesis, but is in fact also incorporated within the method of hypothesis. While Landry believes that the method of hypothesis cannot reach knowledge, I, on the contrary, argue that it can, as long as it is employed within the metaphysical horizon revealed by the theory of recollection. Benson's views are more akin to mine, especially since his recent book offers a detailed account of how elenchus can 
be interwoven with the method of hypothesis (Benson 2015). While my present interpretation is consistent with Benson's, it takes the investigation further in two respects: 1) I provide an explanation for the failure of the method of hypothesis as applied in the Meno; and 2) I explain how elenchus and the method of hypothesis are related to recollection such that, together, the methods and the metaphysical horizon can account for full epistemic success.

The paper proceeds in four parts, elucidating, in turn, elenchus (I), recollection (II), the method of hypothesis (III), and, finally, the possibility of reaching knowledge through intertwining elenchus with the hypothetical method in the metaphysical horizon opened up by recollection (IV).

\section{ELENCHUS IN THE MENO}

The first third of the dialogue consists of Meno's repeated attempts to define virtue and Socrates' rejections of each of these attempted definitions. Socrates rejects Meno's proposals through his typical elenctic arguments: a) Socrates' interlocutor proposes a thesis; b) in his attempt to test this thesis Socrates secures his interlocutor's agreement to further premises; c) Socrates then shows that the initial thesis leads to inconsistencies when combined with some other premises agreed upon. ${ }^{1}$ If no inconsistency is revealed in the last step, the initial thesis has passed the first test. Elenchus is most often taken to mean 'refutation', but the word also has the broader meaning of 'test' or 'cross examination.' Not every elenctic argument has to end by revealing inconsistencies, for sometimes the argument is not carried far enough, and other times there simply is no inconsistency to reveal (see also Vlastos 1983, 39-40). The possibility that elenchus might be used as a test, yet not end by revealing inconsistencies, means that elenchus might be implicitly at work more often than we realize. As I will argue in section III, we use elenchus implicitly as part of the method of hypothesis in testing, deriving consequences, or in putting forth a plausible claim as hypothesis. In cases in which it reveals an inconsistency, elenchus cannot by itself show which one of the premises must be rejected as false. Upon repeated applications, it can, at most, show which premise needs to be rejected as less plausible. ${ }^{2}$

Meno's first definition of virtue consists of a list of virtues corresponding to a variety of classes of people. It enumerates a plurality that is loose, random, and indefinite:

First, if you want the virtue of a man, it is easy to say that a man's virtue is being able to manage the affairs of the city and in so doing to benefit his friends and harm his enemies, and to take care that he may not experience anything like that. If you want the virtue of a woman, it is not difficult to say in detail that she must manage her household well, looking after its possessions and being obedient to her husband. And another is the virtue of a child, whether female or male, and another, again, that of an elderly man, whether free or, if you like, slave. And there are many other virtues, so that one is not at a loss in saying about virtue what it is $(71 \mathrm{e} 1-72 \mathrm{a} 5) .^{3}$

Socrates refutes Meno's account by repeating his demand for a unitary account of virtue. Just as, while there is a wide variety of bees there is just one essence that makes them all bees, so too, regarding virtue, even if there are many and diverse virtues, they all have one and the same form (eidos), through which they all 
are virtues (72c6-d1). ${ }^{4}$ Meno must either withdraw his earlier claim that he really knows what ( $t i)$ virtue is, or provide a new definition, one that respects Socrates' requirement for unity. He opts for the latter.

Meno's second definition of virtue as the 'ability to rule over people' (73c9) appears to display the unified account that Socrates demanded in his earlier criticism. It collapses, however, under Socrates' double criticism: 1) of being too narrow, on account of its failure to apply to children and slaves, for whom it would be inappropriate to rule over their masters and 2) of being too wide, in that it leaves unspecified what kind of ruling corresponds to virtue, i.e. ruling justly, not unjustly.

For his third attempt Meno adopts the poet's words, 'it seems to me, Socrates, that virtue is, just as the poet says, "to rejoice in fine things and have power" and I too say that this is virtue: to desire (epithumein) fine things and to have the power to get them' (77b2-5). The new account is not a bad or false characterization of virtue. Socrates' refutation is intended, I believe, to unmask the distorted worldview that underlies Meno's conception of good things and of the power we need to acquire them.

Socrates begins his examination of Meno's third proposal by showing that its first part, concerning the desire for fine things, is redundant, since no one wants what they consider to be bad. Socrates first clarifies that people who mistakenly desire (epithumein) bad things actually desire them qua good things. He then eliminates the class of people who knowingly desire bad things, for how could anyone desire what makes them wretched and unhappy? Thus, we conclude that no one wants what they consider bad. ${ }^{5}$ What about the second half of Meno's account? Socrates asks Meno if he would include health and wealth among the goods to be acquired. Meno replies that he would, but then mentions only wealth, and, instead of health, introduces political honours and offices (78c6-7). Socrates challenges Meno by showing him that sometimes scarcity or lack are more beneficial than abundance and acquisition of wealth and political honors. Once again, Meno's account is refuted.

Meno's first definition multiplied virtue and conceived of it as corresponding to different categories of people, while privileging man's virtue. On that account, a man's virtue was taken to consist of partaking in the affairs of the city, benefiting friends, and harming enemies, while a woman's virtue was reduced to being submissive to her husband and providing good household management. Meno's second definition conceived virtue as ruling over other people, and thus, implicitly, restricted its availability to men. The third definition restricted the availability of virtue even more, since it reserved it for only wealthy and powerful men when it equated virtue with satisfying desires for wealth and political honors. Close attention shows that the sequence of the three definitions is not random, but rather has a common thread connecting them. The connecting thread is the common belief of privileging courage over virtues like temperance, justice, and piety, that is, privileging what was traditionally considered manly over the so-called co-operative virtues. ${ }^{6}$ Meno's three definitions reveal the increased value placed upon manly virtue and the neglect of the quiet virtues. In his replies, Socrates constructed his challenges in a way that emphasized the need for co-operative virtues alongside manly virtue such as justice and temperance (73a6-c5), justice (73d6-10), and justice and piety (78d-e). Thus he spelled out the dialectical demand for a unitary account.

To conclude this section, I don't see elenchus by itself as being able to establish any 
proposition as true or to justify knowledge. I believe that elenchus has indirect positive contributions insofar as (a) it shows us that we don't know, (b) it shows us how far we are from knowing and how much we thought we knew, (c) it draws out the cluster of inconsistent beliefs that we have, (d) it assists the process of self-knowledge by revealing how little we know, and also, by making us aware of previously unexamined assumptions embedded in our beliefs, it reveals to us that knowledge differs from mere opinion.

\section{RECOLLECTION}

Recollection is introduced to counteract Meno's paradox, according to which search and learning are either futile or impossible, and attempts to show that search is worthwhile and learning possible. Recollection is introduced in two steps, first through myth (81a-e), and then through Socrates' conversation with a slave-boy who, although untrained in mathematics, proves able to discover the solution to a mathematical problem (81e3$86 \mathrm{c} 3)$. In what follows, I am going to sketch the main pillars of the metaphysical and epistemological vision thereby revealed (for my detailed account of recollection in the Meno see Ionescu 2007, 39-104).

The myth says that the soul is immortal. At the end of one's life the soul departs from the perishing body and migrates to a new body. Because the soul is immortal and undergoes successive incarnations without ever perishing, we must live as piously as possible for the quality of our present lives affects the quality of our soul's next incarnation(s). Recollection is then described as an experience available to us on account of our souls' prior 'sight' of pure objects:
And so, since the soul is immortal and has been born many times and has seen both the things here, and those in Hades, and all things, there is nothing that it has not learned. Therefore there is nothing surprising in that it's possible for it to recollect both about virtue and other things, things which indeed it knew before (81c5-9).

The things seen by the disembodied soul are 'the things here, and those in Hades, and all things' (81c6-7). For the tradition preceding Plato, Hades is the underworld. On this reading of Hades, souls would recollect the experiences they had while incarnate and those experiences undergone in the period of purgation between lives in the underworld. Taken together, these make up 'all things' (81c6-7). For the Plato of the Phaedo, Hades is the realm of pure objects of thought, of intelligible and eternal Forms that remain invisible to our sense organs, and therefore, the realm of the Unseen (aidê, aidous, cf. Phaedo 80d6, 81c11). If our passage in the Meno remains inconclusive regarding the nature of the objects thus seen, a fuller account supporting the view that these objects must have the main characteristics of intelligible Forms - eternity, immutability, intelligibility, universality - is supported by Socrates' conversation with the slave (82b-86c).

The conversation with the slave can be divided into six sections: 1$)$ the introduction of the problem (82b9-82e2), 2) the refutation of the slave's first false answer (82e2-83c3), 3 ) the refutation of the slave's second false answer (82c5-83e10), 4) the digression about the slave's state of aporia (84a1-84d2), 5) the slave's acquisition of true opinion regarding the solution to the problem $(84 \mathrm{~d} 3-85 \mathrm{c} 8)$, and, 6 ) the anticipated possibility of turning the slave's present true opinion into knowledge 
(85c9-85d8). Accordingly, knowledge can be achieved in four stages: (a) refutation of false opinions, (b) experience of aporia, (c) acquisition of true opinion, and (d) transition from true opinion to knowledge. The last stage is only announced as a possibility and not actually illustrated during the conversation with the slave, which ends as soon as the boy has reached true opinion. One of the major questions to tackle is: At which of these stages, if any, does the slave begin to recollect? Does he recollect during the occurring conversation, or is recollection reserved for a further stage, which is announced, but never quite witnessed in this dialogue in stage (d)? ${ }^{7}$ I will argue that recollection is already illustrated in the slave's acquisition of true beliefs in stage (c).

The mathematical problem concerns finding the side of a square that is twice the size of a given square. We notice parallels between the mathematical and the moral question. The mathematical problem asks how to obtain the double-sized square while the moral question asks how to obtain virtue. Solving the mathematical problem requires us to identify the line that accounts for the generation of the square similar to the way in which the essence of virtue accounts for the way virtue is acquired in the moral investigation. The essence of virtue eludes precise formulations, just as the length of the diagonal remains inexpressible in numerical language. Finally, just as the diagonal is incommensurable with the given side of two feet because the two lack a common measuring unit, so too, knowing the essence of virtue is incommensurable with common, habitual, and unreflected beliefs.

The slave boy's perception of the drawn diagrams helps his search, but his search does not rely exclusively on sense-perception. ${ }^{8}$ The slave boy relies on his intellect to understand the geometrical concepts of square, equality of sides, and triangle. He comprehends at least two applications of the rule for determining rectangular areas based on multiplication of adjacent sides (82c-d, 83e) and is able to perform arithmetical calculations correctly. $\mathrm{He}$ also understands the abstract relations of doubling, quadrupling, and dividing a whole in half. Finally, when the slaveboy is asked to point out the line he has been searching for, his pointing comes as a result of reflection suggested by Socrates' questions about the relations of double and half, and the concepts of square and triangle. It is in these instances that we witness the non-empirical realities which the slave boy recollects. The slave boy is using the diagram as a physical aid, but he is thinking along of the ideal geometrical shapes themselves, not of their drawn diagrams.

The reasoning in support of recollection resides in showing that a non-empirical component is a sine qua non for knowledge and that the slave is able to understand the solution to a geometrical problem even though he was never formally trained in geometry. ${ }^{9}$ In its simplest form, the argument is that the slave boy could not have recognized the diagonal as the solution to their problem if his soul had not been in possession of latent knowledge. The solution seems to have been stored latently within his soul and, upon Socrates' prompting, the slave boy recollects the answer. Several times during the episode, Socrates points out that he is only asking the slave boy questions and that the boy's answers all stem from his own soul (82b6-7, 82e4-13, 84a3-d1, 85c6-7, 85c9-d4). Moreover, the slave boy is explicitly required to answer only on the basis of what he really believes $(83 \mathrm{~d} 2) .{ }^{10}$ Our understanding of the argument for recollection ultimately comes down to determining the non-empirical nature of the objects of knowledge. Throughout the mythical presentation, the non-empirical 
has been depicted as the region of the preempirical objects envisioned by the soul prior to its embodiment. Throughout the dialectical exhibition with the slave, the non-empirical was illustrated by the ideal and eternal nature of mathematical objects (square, triangle, diagonal, the relations of half, double, equality, etc.). There is no need to make the stronger claim that mathematical objects are Forms as long as they are understood to be universal, unchanging, and eternal realities.

Recollection offers a positive response to the question regarding the possibility of successful search insofar as it provides the metaphysical framework that accounts for the presence of latent knowledge within our soul. Recollection is not itself a dialectical method nor a strategy for reasoning, and as such it does not show us by itself how exactly we go from opinions to knowledge. Rather, it is a theory that explains that and why a transition from opinion to knowledge is possible. It will be the role of dialectical methods like the method of hypothesis or the method of collection and division to show us just how to advance from opinions to knowledge (also Landry 2012, 149)

The epistemological and metaphysical landscape revealed through recollection is built upon the following principles: knowledge has universal, eternal, and unchanging realities for its objects, the human soul has some kinship with its objects, and objects of knowledge are organized in a systematic interrelatedness that reflects the rational organization of reality:

For since all nature is akin (tes physeos hapases sungenous ouses), and the soul has learned all things, nothing prevents it, once it has recollected one thing - what people call "learning" - from discovering all other things if one is courageous and does not weary of the search (81c9-d4). The "kinship of all nature" mentioned in this passage refers, I believe, not only to a rational and systematic interrelatedness of all things insofar as they count as objects of knowledge, but also to an affinity between our soul and the objects thus known. For mere kinship between things to be known can only explain the possibility of the soul's recollecting something else, i.e. 'all other things', from something that it has just recollected, but it cannot explain how the initial thing was recollected. To explain this, we need to assume an affinity between the soul and the objects to be recollected, or else we fall into an infinite regress whereby we are unable to explain how the initial 'seeing' of one thing might have taken place. ${ }^{11}$ The common element that is shared among knowable objects and the soul itself is of the intelligible nature (Rousseau 1981, 337-48, esp. 344-45). Indeed, without the presumed affinity between the soul and its objects of contemplation, we would not be able to account for the fact that awareness of knowledge is a constitutive part of what it means to know (Margaret McCabe 2009, 233-256).

Underlying the story of the soul's prenatal access to truth, its punishments and rewards in Hades, is an articulation of reality in terms of three ontological levels. They are the eternal immutable realities, the immortal soul, and the particular things around us, understood as embodied souls. The soul is akin to the intelligible objects insofar as it shares with them its eternity and incorporeal nature, and it is akin to the particular things around us insofar as it shares their changing nature. It is because the soul shares features with both the particular sensible things and the eternal realities that it can come to know. Through sense organs the soul perceives sensible things; through thinking 
it understands reality in terms of universal and unchanging laws.

Recollection must be understood in its double-aspect. On the one hand, it is a theory that provides the metaphysical landscape within which the possibility of acquiring knowledge is accounted for; on the other hand, it is itself an activity with stages of realization. The slave begins to recollect as he discovers the diagonal of the initial square to be the side of the double sized square and can continue to recollect by reflecting on the reasons that make that opinion true. Still, recollection as a process that takes place in time and has degrees of realization should not to be confused with a dialectical method. Properly speaking, recollection is the cognitive process of understanding that takes place while we are using one dialectical method or another and is facilitated by the use of that method. As a process, recollection describes the cognitive achievement registered while using the systematic steps of a method.

It is commonly said that the slave cannot recollect during elenchus (Irwin 1995, 132, Benson 1990, 128-58, Nehamas 1985, 17-19). One of the common assumptions underlying this view is that recollection represents Plato's novel epistemic theory that is meant to replace Socratic elenchus. Defenders of this position argue that, since true beliefs are typical occurrences in early, elenctic dialogues, and since Plato's new proposal is supposed to 'go beyond' Socrates' elenctic practice, the theory of recollection is meant strictly to explain something that elenchus cannot, namely the transition from true beliefs to knowledge. I believe, however, that recollection is not meant to replace elenchus, but rather to provide the metaphysical and epistemological landscape that accounts for both the limitations and accomplishments of elenchus and/or some other dialectical method. Thus, when elenchus is used within the metaphysical framework opened up by recollection, we understand its role as a method of 'purification'. When the elenchus is used outside of such framework and perhaps within strictly empirical presuppositions, elenchus is a mere logical test for consistency among the beliefs we entertain.

It is perfectly possible to start recollecting even while having your views rejected through elenchus, as long as you begin to understand why those beliefs are rejected as false. In other words, we start to recollect just as we start to grasp what was wrong with the beliefs we used to entertain. To recollect means to grasp the universal and unchanging truth. To the extent that we understand the reasons why our views are being rejected as false, not simply as inconsistent with other beliefs we entertain, we are already engaged in recollection. What matters is the level of abstraction and depth of understanding associated with the views rejected. ${ }^{12}$ It would thus be possible, in principle, for the slave to begin recollecting already while Socrates is rejecting his first false answers. As long as the slave understands not only that his rejected beliefs are inconsistent with the other beliefs he holds, but also why those beliefs are false. Note for instance, Socrates identifies all search with recollection (81d4-5) and also draws Meno's attention to the boy recollecting 'in sequence' while he is refuting the slave boy's false answers (82e12-13). However, given that the slave in this episode is aware only of the inconsistency and misses the reason why his first answers are false, it is possible that he begins to recollect only once he recognizes the diagonal as the side of the double-sized square. ${ }^{13}$

The positive part of Socrates' conversation with the slave culminating in identifying the diagonal has been seen by scholars as parallel to the more constructive conversation with Meno after $86 \mathrm{~d}$. Some scholars have even suggested that the positive step taken with the slave 
already illustrates the use of the hypothetical method (Landry 2012, 160). There is certainly a parallel in that the conversation starts to be more constructive, although I am not completely convinced that we can distinctly identify the method of hypothesis at work already in the conversation with the slave (see also Benson 2003, 153).

\section{THE METHOD OF HYPOTHESIS}

The method of hypothesis is introduced to help us advance from opinions to knowledge. If elenchus helps us to get rid of some views that are inconsistent with the core beliefs we entertain, and the doctrine of recollection offers the metaphysical background justifying, in principle, the possibility of knowledge, then the method of hypothesis suggests a concrete dialectical procedure for positively testing and strengthening our opinions and thereby gradually converting our opinions to knowledge. ${ }^{14}$ My reading of the hypothetical method challenges the traditional interpretations on three accounts. Firstly, I argue that the method of hypothesis is not a diversion or a concession that Socrates makes to Meno, but rather an approach that allows Socrates to investigate the nature of virtue while also winning Meno's participation in the search. Secondly, unlike most commentators who believe that the method's application ends at $89 c$, I argue that the method is applied to the end of the dialogue. ${ }^{15}$ Thirdly, I argue that elenchus is implicitly incorporated into the hypothetical method and helps it all along. ${ }^{16}$

Socrates has just proposed that they take up again the risky and challenging search for the essence of virtue (86c5-7). But Meno wants to return to his initial concern regarding the ways in which virtue can be acquired: whether by teaching, by nature, or in some other way (86c8-d1). Faithful to his maxim that knowing the essence $(t i)$ of something is prior to knowing the derivative qualities of it, i.e. the sort of thing (poion) it is (71a5-b8), Socrates now says that, if he were to rule not only over himself but also over Meno, then they would proceed by investigating the essence of virtue prior to its derivative attributes (86d2-6). However, since Meno is not even trying to rule over himself, and yet he is exerting his rule over his interlocutor, Socrates pretends to comply with his wish in exchange for an apparently insignificant concession. The concession that Socrates is asking for, namely that they investigate the acquisition of virtue starting from a hypothesis, is only ironically introduced as if it were a minor point, whereas it is in fact the device that will reestablish Socrates' control over the search to follow. ${ }^{17}$ Introducing the method of hypothesis under the appearance of yielding to Meno's rule is Socrates' strategy to win his participation again in a joint dialectical search.

Although it has the appearance of a concession to Meno, hypothetical reasoning in fact enables Socrates to remain faithful to his maxim that knowledge of the essence is prior to knowledge of the derivative qualities. ${ }^{18}$ By reducing Meno's question, whether virtue is teachable, to the preliminary problem of whether virtue is some sort of knowledge, Socrates basically brings Meno closer to the question concerning the nature of virtue (Benson 2003, 109-110; Benson 2015, 95-102). Furthermore, it would be implausible for Socrates to be so easily diverted from what he conceives to be the main task at hand, especially after he introduced recollection as a theory that guarantees the possibility of epistemic success. Besides, throughout the dialogue, Socrates never retracts the maxim that knowledge of the essence precedes knowledge of a thing's derivative qualities (71b-c). In 
fact, at the end of the dialogue, he restates the maxim for the specific case of virtue under consideration (100b). Finally, the use of alla ('at any rate', 'but') when Socrates addresses Meno with the words, 'If you won't grant me anything else, at any rate (alla) relax your mastery of me to a small extent and allow the question whether virtue comes by teaching or in some other way to be examined from a hypothesis' (86e1-3), is indicative of a break from Meno's demand (Denniston 1959, 11-13, Bedu-Addo 1984, 2, Bluck 1961, 321-22).

Hypothetical reasoning is borrowed from geometry and is therefore appropriately illustrated with a geometrical problem. The geometrical problem is whether a given area is inscribable as a triangle in a given circle, while the moral problem is whether virtue is teachable. The hypothetical method recommends reducing a more difficult problem to a simpler one that needs to be answered first and that sets limiting conditions for the other. Thus, in the mathematical case, the question as to whether the area is inscribable as a triangle in the given circle, is reduced to determining whether the area is such that, when one places it alongside its given line, it falls short by a figure similar to the one that was placed alongside. In the moral case, the problem as to whether virtue is teachable is reduced to the problem of whether virtue is some sort of knowledge, since virtue being some sort of knowledge is identified as a limiting condition for it being teachable.

There is a long-standing debate over whether the initial hypothesis is 'virtue is some sort of knowledge' or the biconditional 'if virtue is some sort of knowledge, it is teachable, if not, it is not teachable' (87b6-c9). I agree with BeduAddo and Benson in regarding this debate as a red herring insofar as Plato allows more than one hypothesis. Rather than deciding which of the two claims is the initial hypothesis, it is more important to recognize the key elements of the hypothetical procedure: i) that the hypothesis is proposed tentatively and provisionally, ii) that it establishes limiting conditions and then iii) considers whether the limiting conditions announced have been met (BeduAddo 1984, 6, Benson 2003, 107, 112-113).

Let us take a look at the steps of the hypothetical method's application to our quest for the essence of virtue. In a synoptic overview, the final part of the dialogue (86d-99e), developed entirely within the framework of hypothetical reasoning, proceeds according to the following stages:

Stage 1: Socrates proposes the biconditional hypothesis 'If virtue is like knowledge or some sort of knowledge, it is teachable, if not, not' as a plausible assumption that licenses the reduction of Meno's question of whether virtue is teachable to the problem of whether virtue is some sort of knowledge (87b5-c10).

Stage 2: The problem of whether virtue is some sort of knowledge is solved, though only provisionally, by appeal to another hypothesis, 'virtue is good' from which 'virtue is wisdom or some sort of knowledge is derived' (87c11-89a5).

In this stage, we gain more support for the view that 'virtue is knowledge' by deriving it from an antecedent assumption, 'virtue is good'; while in the following stages we are trying to secure the same view, by testing how its equivalent claim, 'virtue is teachable', sits in relation to what seem to be some of its necessary consequences, i.e. that it is not simply inherited by nature (Stage 3 ) and that there are teachers and learners of it (Stage 4). ${ }^{19}$

Stage 3: Socrates draws a corollary that human beings do not possess virtue by nature from the conclusion that virtue is some sort of knowledge and therefore teachable. He then confirms this by appeal to a counter-factual situation (89a5-c2). As we shall see, this stage 
marks the transition from Socrates' understanding of virtue, knowledge, and teaching assumed in the previous two stages, to Meno's and Anytus' understanding of these concepts assumed in the following stages. I argue that it is ultimately this shift in meaning that is responsible for the fact that the method of hypothesis ends without a successful attainment of knowledge about virtue in the Meno.

Stage 4: The view that virtue is teachable is examined by testing whether one of its (problematically) presumed necessary consequences is true, namely the existence of teachers and learners of it (89d1-96d). Existence of teachers and students is regarded as a necessary consequence of virtue being teachable. Since neither adequate teachers nor learners of virtue can be found, virtue is not teachable.

Stage 5: The result obtained in Stage 4 prompts Socrates to revise one of the assumptions that seemed to be employed in the derivation of 'virtue is wisdom' from 'virtue is good' in Stage 2. This move leads to the problematic conclusion that virtue accrues to humans by divine dispensation (99e). ${ }^{20}$

As I argue in what follows, the arguments developed in the first two stages (87b5-89a5) proceed on the basis of Socrates' understanding of knowledge, virtue, and teaching, while the arguments developed throughout the following three stages of the method, depend almost entirely on Meno's and Anytus' (mis) conceptions about these notions. ${ }^{21}$ This shift explains why the results obtained in the investigation carried under Meno's and Anytus' assumptions about knowledge, teaching, and virtue, do not represent a real threat to the results obtained in Socrates' argument at 87d-89a. Thus, Socrates' view that virtue is wisdom, and therefore teachable, resurfaces unharmed in the concluding passage, where Socrates envisions the possibility of a genuine teacher of virtue on account of his wisdom (pepnumai) at 100a1-5.

Let's then take a look at each of the stages of the hypothetical method's application and spot applications of elenchus along the way.

Stage 1: The hypothesis is established in stages. First, Socrates obtains Meno's agreement to the negative conditional 'If virtue is of a sort other than knowledge, then it is not teachable' (87b6-c4), and then to the positive conditional 'If virtue is some sort of knowledge, virtue is teachable' (87c5-6). Thus, the argument to the hypothesis has the following structure:

(1) A human being is taught nothing other than knowledge (87c2-4).

(2) If virtue is of a sort other than knowledge, it is not teachable (87b7-c4) (from 1). (3) If virtue is some sort of knowledge, virtue would be teachable (87c5-6) (independent assumption).

(4) Therefore, if virtue is some sort of knowledge, it is teachable, if it is other than knowledge, not (87c8-9) (from 2 and 3).

Once the hypothesis has been reached, Socrates proceeds to investigate the problem to which Meno's question has been reduced, namely whether virtue is some sort of knowledge.

Stage 2: Socrates investigates whether virtue is some sort of knowledge by appealing to a new hypothesis. The new hypothesis functions as a more basic condition for the possibility of virtue being knowledge, in that sense a 'higher' antecedent assumption: 'virtue is good' ( $87 \mathrm{~d} 2$ 3 ), and derives "virtue is some kind of knowledge" from "virtue is good" by means of the following reasoning:

(1) Virtue is (something) good (87d2-3). 
(2) Virtue is that by which we are good (87d8-e1).

(3) All good things are beneficial (87e2).

(4) Therefore, if we are good, we are beneficial (87e1-2) (from 3).

(5) Virtue is beneficial (87e3) (from 1 and 3 ).

(6) Virtue is something in the soul (88b).

(7) Wisdom or some sort of knowledge alone is invariably beneficial and good (established through a separate argument, 87e5-89a5).

(8) Therefore, virtue is wisdom, either the whole or part of it (89a3-4) (from 5, 6 , and 7).

The seventh premise is established through an independent argument (87e5-89a5). The argument first establishes that wisdom is necessary for our right use of the benefits from the goods of the body, like health, strength, beauty, and wealth. Then, it establishes that wisdom is the necessary accompaniment of valuable things connected to the soul, and is the only thing invariably good.

Stage 3: Once we have derived, if only provisionally, 'virtue is wisdom or some sort of knowledge' from its antecedent assumption that 'virtue is good', Socrates proceeds to test the consequences of that derivation by means of elenchus. How do the necessary consequences of virtue being knowledge, and thus teachable, match up with the facts?

As a corollary of the reasoning carried so far, Socrates derives the view that human beings do not possess virtue by nature, which he confirms by appealing to a counter-factual situation. If virtue were possessed by nature, then there would presumably be people looking to see which children were born good, and everyone else would recognize them as such and guard them from corruption in the polis (89a5-b8). But it is striking that the argument by appeal to the counter-factual situation is not at all convincing because it rests on several problematic assumptions: a) that nature and teaching are mutually exclusive ways of acquiring virtue, $b$ ) that there are experts able to discern good people, and c) that the masses would readily agree with the experts' judgments. Nothing in the dialogue encourages us to believe that Socrates himself endorses any of these assumptions.

The claim that nature and teaching are assumed to be mutually exclusive candidates for the accrual of virtue transpires throughout the present argument, namely if people were good by nature, life in the polis could do nothing but corrupt them, and if people were to possess virtue by nature, then good people would be easily discernable while still very young. On Socrates' understanding of 'nature' and its intelligible kinship with the soul, which emerged from the recollection story, nature and learning (recollection) complement one another (81c5-9). On Meno's understanding of 'nature' as the sum of features inherited biologically from our parents, and 'learning' understood as memorization of readily given answers, 'nature' and 'learning' exclude one another as sources for the accrual of virtue. This claim seems to be suggested by Meno throughout his initial formulation of the opening question (70a1-4). The argument also assumes that the masses are immediately and non-problematically persuaded to give due recognition to the experts' judgment regarding the young's moral natures. But if this were the case, the masses should be credited with high moral character, and, if so, it would be unreasonable to assume that they are somehow corrupting the young. Finally, the argument recognizes that there are different kinds of people living in the polis: some are experts who are able to recognize the 
good natures of the newly born, while others only obey the experts' judgment. However, for Socrates at least, the moral experts who can discern good characters should themselves be good people, and thus we wonder how they could have managed to keep their own good natures uncorrupted in the city.

Since we have no reason to believe that Socrates endorses any of these problematic assumptions on which the claim about the irrelevance of nature in the accrual of virtue is based, I believe that we are witnessing here a silent transition from Socrates' understanding of 'knowledge as recollection' to Meno's and Anytus' understanding of 'knowledge as persuasive opinions acquired through sophistic instruction', which will be at work throughout the remaining part of the text. Evidence for this view comes immediately in following stage, where the existence and success of teachers of virtue come to the forefront.

Stage 4: In the next stage, whether virtue is teachable is tested by investigating whether one of its assumed necessary consequences, namely the existence of teachers and students, harmonizes with the facts (89d-96d). The argument takes the following form:

(1) There are no effective teachers of virtue (89e4-96b9).

(2) If there are no teachers (of virtue), there are no learners (of virtue) (96c1-2).

(3) A subject of which there are neither teachers nor learners is not teachable (96c3-5).

(4) Therefore, virtue is not teachable (96c10-d1) (from 1, 2, and 3).

The first premise is established through an independent and lengthy conversation during which specific classes of potential teachers of virtue are first proposed and then rejected. The argument's approach is framed by the question: Who are the appropriate teachers to whom Meno should go in order to acquire the kind of virtue that he wants (91a-b5)? This formulation clearly suggests that the reasoning now rests on a conception of virtue that suits Meno and Anytus, not Socrates. In support of this, notice also that when Socrates describes to Anytus the kind of virtue for which they are now searching for teachers, Socrates' description restates in a condensed manner the essentials of Meno's first attempted definition of virtue (71e1-72a5). In Socrates' words:

For, Anytus, he has for a long time been telling me that he desires the wisdom (sophia) and virtue by means of which human beings manage their households and cities well, and look after their parents, and are knowledgeable of how to receive fellow-citizens and foreigners and how to send them away in a manner that's worthy of a good man (91a2-b1).

Differences between the two formulations are minor and merely superficial. Meno's definition assigned specific virtues to particular classes while the new formulation takes a rather undifferentiated approach. Meno assigned household management to women and citymanagement to men, while they are now both attributed to people generally. Meno framed the talk about human interactions in terms of benefiting friends and harming enemies, but now the others are referred to as fellow-citizens and strangers, a change that suits Anytus' political perspective. Looking after one's parents is a new aspect, an addition that suits Anytus' conventional praise for tradition. None of these changes affects substantially the content of virtue, and the fact that neither Meno nor Anytus find anything objectionable to the conception 
here stated suggests that they both endorse it. Evidence to the same effect comes also from Socrates' formulations. His formulations emphasize that it is this understanding of virtue, namely Meno and Anytus' understanding, that is assumed in what follows: "So, with regard to this virtue (tauten ten areten...), consider whom would it be right for us to send him to" (91b1-2). Socrates' formulation also uses 'paradounai' (93b4-5) to indicate the kind of 'transfer' of information presupposed by the teaching here envisioned, a characteristic of the sophists' or craftsmen's instruction, not of recollection (87b6-c1).

The argument relies on a close analogy between virtue and the crafts (technai, 90b591a1). If Meno wanted to become a doctor he would be sent for lessons to professional doctors, if cobbler to cobblers, if flute-player to flute players, and so with all the other crafts (90c-d9). In any craft, experts are those who recommend themselves as teachers and charge a fee in exchange for the lessons they teach (90d-e). Therefore, Meno needs to be sent to people who recommend themselves as teachers of virtue and charge a fee in return for their teaching (91b2-6). The most plausible candidates for this role - the sophists (91c-92c, 95ac8) and the Athenian gentlemen (hoi kaloi kagathoi, 92d-94e) - will be considered and rejected through elenctic reasoning, thus leading to the conclusion that there are no teachers of virtue.

When Socrates recommends the sophists as teachers of virtue, Anytus rejects this proposal by claiming that the sophists harm those who associate with them (91c1-5). Socrates brings a counterargument and a counterexample: but look at Protagoras! How could Protagoras have escaped public criticism and maintained his good reputation for more than forty years, had he really been harming rather than benefiting his followers? Socrates himself does not believe that the sophists are successful teachers of virtue, but he challenges Anytus because he wants to reveal Anytus' unreflective reliance on common opinions. Anytus has to either revise his rejection of the sophists, or find a way to discredit Socrates' evidence on behalf of Protagoras' success.

When Anytus proposes the kaloi kagathoi as teachers of virtue, Socrates uses elenchus to challenge this view:

1) The kaloi kagathoi are teachers of virtue.

2) If any of the kaloi kagathoi were teachers of virtue, Themistocles, Aristides, Pericles, and Thucydides would have been.

3) If Themistocles, Aristides, Pericles, and Thucydides had been teachers of virtue, they would have taught their sons to be good.

4) The sons of Themistocles, Aristides, Pericles, and Thucydides were not good. ${ }^{22}$

Anytus has to either give up his candidates, or show that Socrates' conclusion about the Athenian gentlemen does not follow.

Socrates need not endorse the view that for a subject to be teachable there always need to exist teachers prepared to teach it, and that in the absence of such teachers the subject is not teachable. In fact, in the Republic VII, Socrates invokes the case of solid geometry as an example of a discipline for which no teachers are to be found (Rep. 528b-c).

Stage 5: The conclusion that virtue is not teachable prompts Socrates to ask whether they need to revise one of the assumptions that seemed to be employed in the derivation of 'virtue is wisdom' from 'virtue is good' in Stage 2. This shows that the arguments that 
follow are developed within the hypothetical framework set forth by the initial biconditional hypothesis that virtue is some sort of knowledge if and only if it is teachable. Since the preceding stage concluded that the latter term of this equivalence 'virtue is teachable' is false, it now appears necessary that the former 'virtue some sort of knowledge' must also be false, if the hypothesis holds true.

The ending of the dialogue appears confusing at first sight. Does Socrates endorse the view that virtue comes by divine dispensation? Is he truly recanting the view that virtue is wisdom or some sort of knowledge? Or is he recanting his view that it can be taught, after he went through the pains of explaining teaching as recollection? I doubt that he does so. I believe that we are invited to recognize that the last portion of the conversation proceeds under the assumptions of virtue, knowledge, and teaching that Meno and Anytus endorse, while Socrates doesn't. Stage 4 only showed that it is plausible that virtue, on Meno's and Anytus' understanding of it, is not teachable. Correspondingly then, we are not asked to accept the falsity of virtue's association with knowledge on Socrates' understanding of virtue and knowledge, but only on Meno and Anytus' understanding of those.

Scholars have typically adopted one of two routes in trying to make sense of the dialogue's ending. Some of them argue that Plato has finally come to give up the initial Socratic intellectualistic ideal that identified virtue with knowledge and adopted a more realistic stance, according to which true opinion is sufficient for virtue (Bluck 1961,19-30). Others argue that the reasoning in Stage 3 is flawed and Plato does not endorse its result (Devereux 1978, 122-3, Bedu-Addo 1984: 10-14, Gonzalez 1998,180). I agree with the latter camp, all the more so since in the final lines, Socrates envisions the possibility of a genuinely virtuous teacher of virtue on account of wisdom (100a1-7). We thereby witness in the concluding scenario a revival of Socrates' understanding of virtue, knowledge, and teaching. I believe that Plato's strategy of arguing to a hypothesis first, then challenging it is meant to reveal essential aspects of this dialectical method. First, it emphasizes that accepting the provisional status of hypotheses is central. Furthermore, it suggests, I believe, that Socrates envisions the possibility of taking the hypothetical method a step further. The claim that is rejected in Stage 3 is that knowledge alone is good. One can replace that view with a refined and revised claim that takes into account the ground for the newly revealed distinction between opinions and knowledge. True opinions are good and beneficial while they last, but the trouble is that they don't last for long. Knowledge, however, is stable and invariably good and beneficial. If we are ready to qualify the claim about knowledge and show that knowledge alone is stable and invariably good and since virtue itself is also stable and invariably good, then we can make sense of the possibility of this virtuous teacher envisioned in the last line, for he would be a teacher on account of his knowledge, not of mere opinions. The claim of invariability and universality, however, cannot be firmly grounded empirically and requires anchoring in universally stable and unchanging a priori principles.

Socrates can then maintain his view that virtue is wisdom (some sort of knowledge) if he construes his argument in the following way:

(1) Virtue is good (87d2-3).

(2) All that is good is beneficial (87e2).

(3) Correct action is guided either by true opinion or by knowledge (96d5-98c, 97b9-10). 
(4) Virtue is stable.

(5) The virtuous person must always have direct personal experience of virtue.

(6) True opinion is not stable (97c-98a).

(7) True opinion does not necessarily presuppose direct experience of its object (97b).

(8) Knowledge is stable (97c-98a).

(9) Knowledge always presupposes one's direct experience of its object (97b).

(10) Therefore, virtue is some sort of knowledge.

While Socrates never argues explicitly for premises (4) and (5), nevertheless, the entire conversation developed throughout the Meno, and the fact that the dialogue ends with Socrates' optimistic scenario envisioning the possibility of a genuine teacher of virtue on account of knowledge (wisdom), invite us to think that he endorses them. The idea that virtue is stable results implicitly from the argument at 87b-89a5 coupled with the argument at 97c1198a8. In the earlier context, Socrates argued that wisdom alone is invariably good and that it is a necessary condition of virtue (88a6-89a5). The later context (97c11-98a8) argues for the stability of knowledge. Since wisdom is conceived as some sort of knowledge, and since its presence in the soul is necessary for virtue, virtue itself is likely conceived as stable. The idea that the virtuous person must have some direct personal experience of virtue was also implicitly suggested in what went on before. When he introduced the theory of recollection, Socrates mentioned virtue as one of the objects that can be recollected (81c8). And the episode with the slave showed that to recollect means to recover truths through one's own reasoning, and that personal reflection and direct grasp of its objects are necessary conditions of knowledge. As long as the hypothesis that virtue is some sort of knowledge remains, possession of virtue presupposes one's direct intellectual experience of it.

\section{THE POSSIBILITY OF ACQUIRING KNOWLEDGE THROUGH INTERTWINING ELENCHUS WITH THE METHOD OF HYPOTHESIS IN THE METAPHYSICAL HORIZON OF RECOLLECTION}

Let us now bring together our findings and look at the way in which elenchus, the hypothetical method, and recollection are interrelated. As applied throughout the first third of the dialogue (71d-79e), as well as through the first part of the conversation with the slave (82b-84c), elenchus leads to acknowledgement of inconsistencies among one's beliefs and culminates in a state of perplexity. Although elenchus, by itself, is unable to offer a standing foundation for our beliefs and turn them into knowledge, it nonetheless aids the process of tethering opinions down to a certain extent. The main positive functions of elenctic arguments emerging from the earlier analysis can be summarized as follows: (i) constant re-examination of our opinions strengthens their grounds and gradually makes them quasipermanent; (ii) Socrates' use of elenchus encourages us to continue the search and guards us against skepticism; (iii) elenchus draws out the real meaning of other people's beliefs and thus gives us a better understanding of their views. While opinions accepted completely uncritically on the basis of external authority or lucky guesses are liable to frequent and quick changes, opinions accepted upon elenctic examination are much more stable (Gorgias 482a7-b1, 508e-509a, Crito 46b-e, 54d). 
Far from dropping his elenctic practice once he introduces the hypothetical method, Socrates actually makes use of the former in applying the latter. First, when deriving 'virtue is wisdom' from "virtue is good" (87c-89a), then, in refuting the belief that 'virtue is teachable' (90a-96d), and finally in reconsidering the scope of the class of good things, adding true opinion along with knowledge (97a-99e).

Though related in many ways, hypothetical method and elenctic arguments also differ from each other: (a) hypothetical reasoning explicitly acknowledges the provisional nature of the opinions put forth, while elenchus does it only indirectly; (b) the main goal of elenchus is to secure coherence among one's beliefs, while that of the hypothetical method is to also ensure the systematic interrelatedness of a coherent set of beliefs and to gradually lead to the most basic antecedent assumptions of these beliefs; (c) elenchus always starts from a belief endorsed by its proponent, whereas the hypothetical method often begins from statements not (yet) assented to (see also Landry 2012, 153-154; Benson 2003). As we have seen, however, none of these differences obstructs the collaboration of the two methods.

The method of hypothesis was introduced with the aim of leading us to knowledge. In the episode that we witness in the Meno the final successful result is not achieved. Can the method of hypothesis achieve full success by leading to knowledge? Landry believes it cannot:

[By means of the method of hypothesis] we can only come to have true opinions about the qualities of an object of search. This because, so long as we tether from an hypothesis (as opposed to tether to an object), we might, in our deductions or construction, assume a questionable premise which will then require that we question our conclusion and so too our hypothesis. As Socrates shows Meno with respect to the nature of excellence, so Plato shows us with respect to the nature of philosophical knowledge: our true opinions, in so far as they are tethered from an hypothesis via the mathematician's method, though they might be a guide for acting as if we know the object itself, so that we can construct or deduce its qualities, cannot provide a tether to the object itself, and so cannot provide a means for knowing the object itself. (Landry 2012, 155)

Thus, Landry continues, while the hypothetical knowledge is beneficial in that it can yield mathematical knowledge (which aims only to tether from an hypothesis), it is limited in that it cannot yield philosophical knowledge (which aims to tether to the object itself). I, however, believe that, when understood in the horizon opened by recollection, the method of hypothesis can lead to knowledge. I disagree with Landry that the method of hypothesis is restricted to the mathematicians' use and thus, we need another method for the philosophers' use that would end with knowledge. Rather, I believe that when the method of hypothesis is in a philosopher's hand, i.e. in the hand of someone ready to engage in recollection of the most abstract and ultimate forms including the Good, it is a philosopher's method and thus can reach knowledge. The Meno gives us only a hint of how the philosopher might proceed in using it in order to advance to knowledge, while the Phaedo and the Republic elaborate in more detailed and explicit ways on how that can be done (See Benson 2006, 85-99). The condition, however, for the method to succeed is that it must be used in a metaphysical horizon akin to that described by recollection, 
namely a horizon that guarantees the existence of universal, eternal, and unchanging truth.

Socrates introduced the theory of recollection in order to show that knowledge and learning in general are possible. The possibility of eventually reaching and recognizing the truth is guaranteed by the affinity between our reason and the rationality of the world (the "kinship of all nature", cf. 81c9-d1). When the dialectical method of search is carried far enough, recollection guarantees attainment of knowledge. Thus, in our case, if the method of hypothesis is carried far enough, that is, if we investigate by its means the conditions for the possibility of virtue being stable, eternal, unchanging, and good, and if knowledge also shares all of these qualities and is instrumental to virtue, we can, in principle, turn into knowledge our current opinions about the relation between virtue and knowledge. Landry is right to think that, as uttered in the Meno, the claims 'virtue is good' and 'virtue is knowledge' are mere true belief as they ground the understanding of the Good itself. But if we trust that recollection can in principle give us access to the Good itself, we can expect to turn the current opinions into knowledge. The difference will be reflected not in the linguistic expressions that we use to speak of it, but in the disposition of the soul contemplating that truth. In other words, the same linguistic expression can be stated sometimes as opinion and at other times as knowledge.

If the account here proposed is correct, elenchus and the method of hypothesis are to be seen as working hand in hand. Elenchus signaling inconsistencies that allow the method of hypothesis to move forward and select more and more plausible claims as hypotheses to be tested and eventually tied down with reasons confirming them. However, coupling these two methods is not sufficient for reaching knowledge. All they can do by themselves is increase the consistency among our beliefs, but this offers no guarantee that we are heading to knowing the way things are. This is where the theory of recollection becomes crucial, as a metaphysical account that explains the possibility of these dialectical methods to help us advance from mere opinions to knowledge. The kinship between the soul of the knower and the intelligible aspects of the objects under investigation, which recollection both presupposes and accounts for, guarantees at once our ability to identify truth when encountered, our awareness that we know when we do, and our ability to advance from one thing recollected to another, and thus understanding the objects of search in a network and not as mere isolated items.

\section{BIBLIOGRAPHY}

Adkins, A.W.H. 1990. Merit and Responsibility, Oxford: Clarendon Press.

Bedu-Addo, J. T. 1984. "Recollection and the Argument 'from a Hypothesis' in Plato's Meno.".

Journal of Hellenistic Studies 104:1-14.

--. 1983. "Sense Experience and Recollection in Plato's Meno", American

Journal of Philology 104: 228-48.

Benson, Hugh. 1990. "Meno, the Slave Boy and the Elenchos” Phronesis 35: 128-158.

- - 2003. "The method of hypothesis in the Meno", Proceedings of the Boston Area

Colloquium in Ancient Philosophy 18: 95-126.

- -. 2006. "Plato's Method of Dialectic" pp. 85-99 in Benson ed., A Companion to

Plato, Blackwell Publishing.

- - 2015. Clitophon's Challenge: Dialectic in Plato's Meno, Phaedo, and Republic, Oxford University Press.

Bluck R. S. 1961. Plato's Meno, Cambridge: Cambridge University Press. 
Bostock, David. 1986. Plato's Phaedo. New York: Oxford University Press.

Brown, Malcolm. 1967. "Plato Disapproves of the Slaveboy's Answer”, Review of Metaphysics 21: 57-93.

Buchmann, Klara. 1936. Die Stellung des Menon in der Platonischen Philosophie, Leipzig: Dietrichsche Verlagsbuchhandlung.

Crombie, I. M. 1963. An Examination of Plato's Doctrines, Vol. 2, New York: Humanities Press.

Devereux D.T. 1978. "Nature and Teaching in Plato's Meno", Phronesis 3:118-126.

Dunlop, Charles. 1975. "Anamnesis in the Phaedo," New Scholasticism 49: 51-61.

Fine, Gail. 1992. Inquiry in the Meno pp. 200-226 in R. Kraut ed. The Cambridge Companion to Plato, Cambridge University Press.

- - 2004 "Knowledge and True Belief in the Meno" in Oxford Studies in Ancient Philosophy 27 (1): 41-81.

Gallop, David. 1975. Plato: Phaedo, Oxford: Clarendon Press.

Gentzler, J. 1994. "Recollection and the Problem of the Socratic Elenchus," Proceedings of the Boston Area Colloquium in Ancient Philosophy 10: 257-95.

Gonzalez, Francisco. 1998. Dialectic and Dialogue: Plato's Practice of Philosophical Inquiry. Evanston III.: Northwestern University Press.

Grote, G. 1867. Plato and the Other Companions of Socrates, London.

Gulley, Norman. 1954. "Plato's Theory of Recollection," Classical Quarterly 4: 194-213.

- - 1962. Plato's Theory of Knowledge. London: Methuen\& Co. Ltd. Ionescu C., 2007. Plato's Meno: An Interpretation, Maryland: Rowman \& Littlefield, Lexington Books.

Ionescu, Cristina. 2007. Plato's Meno: An Interpretation, Lanham, MD: Rowman and Littlefield

Irwin, Terrence. 1995. Plato's Ethics. New York: Oxford University Press.

Klein, Jacob. 1965. A Commentary on Plato's Meno. Chapell Hill, NC: University of North

Carolina Press.

Kahn, Charles. 1996. Plato and the Socratic Dialogues. Cambridge, UK: Cambridge University Press.

Landry, Elaine. 2012. "Recollection and the Mathematician's Method in Plato's Meno",

Philosophia Mathematica (III) 20: 143-169.
Liddell H.G. \& R. Scott, 1996. Greek-English Lexicon ( $9^{\text {th }}$ Edition, revised and augmented by

H.S. Jones and R. McKenzie, Oxford: Clarendon Press.

McCabe, Mary Margaret. 2009. “Escaping One’s Own Notice Knowing: Meno's Paradox

Again", Proceedings of the Aristotelian Society, vol. 109, pp. 233-256.

Meyers, Judith. 1988. "Plato's Geometric Hypothesis: Meno 86e-87b," Apeiron 21: 173-80.

Moravcsik, 1970. "Learning as Recollection", in Plato: A Collection of Critical Essays edited by

Gregory Vlastos, New York: Doubleday and Company, Inc.

Nehamas, Alexander. 1985. "Meno's Paradox and Socrates as a Teacher", Oxford Studies in

Ancient Philosophy 3: 1-30.

Rankin, H.D. 1958. "Immediate Cognition of Forms in the Phaedo?" Dialectica 12.

Robinson, Richard. 1953. Plato's Early Dialectic, Oxford: Clarendon Press, $2^{\text {nd }}$ ed.

Rose, Lynn E. 1970. “Plato's Meno 86-89," Journal of the History of Philosophy 8: 1-8.

Ross, David. 1951. Plato's Theory of Ideas, Oxford, UK: Clarendon Press.

Rousseau, Mary F. 1981. "Recollection as Realization - Remythologizing Plato," Review of Metaphysics 35: 337-48.

Scott, Dominic. 2006. Plato's Meno. Cambridge, UK: Cambridge University Press.

Seeskin, K. "Vlastos on Elenchus and Mathematics," Ancient Philosophy 13 (1993): 45-46.

Seeskin, K. 1987. Dialogue and Discovery, Albany: State University of New York Press.

Sternfeld, R. and Zynskind, H. 1978. Plato's Meno: A Philosophy of Man as Acquisitive.

Carbondale, IL: Southern Illinois University Press.

Tigner, Steven S. 1970. “On the 'kinship of all nature' in Plato's Meno", Phronesis 15: 1-4

Vlastos, Gregory. 1965. "Anamnesis in the Meno", Dialogue 4: 143-67.

- - 1988. "Elenchus and Mathematics: A Turning Point in Plato's Philosophical Development", American Journal of Philology 109: 362-396.

- - 1983 "The Socratic Elenchus" reprinted as pp. 36-63 in Gail Fine ed., Plato I: Metaphysics and Epistemology, Oxford University Press, 1999.

Weiss, Rosslyn. 2001. Virtue in the Cave: Moral Inquiry in Plato's Meno, New York: Oxford University Press. 


\section{NOTES}

1 Scholars sometimes distinguish between direct and indirect elenchus. See, for instance, Robinson 1953, 22-26. The difference between the two is that indirect elenchus refutes a thesis by deducing a falsehood from that thesis in conjunction with some other accepted premise(s), while direct elenchus reaches the contradictory of the initial thesis without making that thesis a premise in this argument, that is, without ever assuming the truth of the refutand. Robinson argues that the former type is the most frequent in Plato's dialogues (24). The general stages of elenctic arguments presented above suit both forms. The difference is that in indirect refutation the thesis proposed in step a) is taken as one of the premises from which the conclusion will be derived (reductio ad absurdum), while in direct refutation the thesis initially proposed is never assumed as a premise.

2 Fine takes a different view. She argues that elenchus can lead to true opinion and knowledge: 'elenchus need not end in aporia; the elenctic method can take one all the way to knowledge. To show this, Socrates questions the slave further, until the slave eventually states the right answer (84d-85b); this further stage of questioning involves the elenctic method no less than does the initial stage, and so Plato shows that the elenchus can go beyond the exposure of ignorance to the articulation of true beliefs' (Fine 1992, 208-9). I believe that Fine is right to say that elenchus need not end in aporia and can contribute to positive results. However, I cannot agree with the claim she seems to be making that elenchus can lead to knowledge all by itself; to lead to knowledge elenchus needs to be supplemented by (an)other method(s) of search, whether the method of hypothesis or collection and division, or some other dialectical approach. Fine is right that all that Socrates needs to do to lead the slave to knowledge is to keep questioning him until he gives the right answer, but we need to acknowledge that Socrates' questioning cannot proceed randomly and it leads best when its steps and trajectory follow the strategy of a dialectical method that is not reducible to elenchus, but rather incorporates elenchus into a more constructive approach. In addition, while elenchus plus some more constructive approach might lead to knowledge, we cannot really account for that achievement as knowledge in the absence of a metaphysical account like the one provided by the theory of recollection. To put it simply, it is only within the metaphysical horizon of recollection that elenchus becomes a method of purification and thus, at least indirectly a method that guides us in the direction of knowledge (even if it doesn't reach that final stop by itself), whereas without the metaphysical horizon of recollection elenchus is a mere test for internal consistency of a belief set, and not yet a practice of purification. 3 Unless otherwise specified, translations are mine. 4 Scholars like Klein and Bluck warn us about the sense of eidos in this context (Klein 1965, 48-50, Bluck 1961, 22127). In particular, they argue that we should not identify its meaning here with the technical sense it acquires in Plato's later dialogues as part of his elaborated 'theory of Forms'. Although an account of Forms is not explicitly developed in the Meno, and although ousia and eidos have here (72b1-e) the general meaning of an explanatory account or cause for a thing's being what it is, later parts of the Meno, and in particular the theory of recollection (81a-86d), are based on the implicit assumption of Platonic Forms. Since, as we shall see, part of the dialogue's message is that only a reply in terms of intelligible universal objects conceived on the model of Platonic Forms can adequately satisfy Socrates' search for the essence of virtue, it is plausible to regard the present use of eidos as a first stage in Plato's development of his mature theory. To support the view that Plato himself conceived of the Socratic search for eidos as convergent and continuous with his mature thoughts about Forms, let us notice that when Socrates attempts to determine the metaphysical and epistemic status of Forms in the Phaedo (65d), the first Forms that he mentions are the same three instances (size, health, and strength) that he uses in the Meno in the immediately following analogy with the essence of virtue (Meno 72d). In addition, the frequent designation of Forms as to ho esti (Phaedo 74d6, 75b1, 75d2, 78d4, 92d9) suggests again the continuity with the $t i$-question raised in the earlier dialogues, and in particular with the Meno's reference to virtue as what it is itself by itself (auto kath auto ti estin aretê, 100b7) (Kahn 1996, 337-38 also points out these connections).

5 In the Meno Socrates does not undertake the task of proving the stronger claim that, in spite of our actual irrational or mistaken desires for bad things, we all actually have also a deeper, rational desire for what is really good, the way he does in the Republic.

6 On the traditional view, going back to Homer, Greeks used to distinguish between manly virtue (courage), on the one hand, and qualities such as wisdom, justice, temperance, and piety, conventionally called by scholars quiet or co-operative virtues, on the other. Manly virtue has to do primarily with the individual in and for himself, quiet virtues with human interactions in the city. Courage used to be associated primarily, if not exclusively, with men, while the co-operative virtues were primarily associated with women and were considered of inferior value. Meno generally subscribes to common traditional views and the superiority of manly over cooperative virtues is one of the common opinions that he endorses. The traditional view that courage is of highest value for men is also reflected in the linguistic connection between andreia (courage) and anêr (man). Andreia literally means manliness or manly spirit; being andreios means to be truly a man. Cf. H.G. Liddell \& R. Scott, Greek-English Lexicon 1996. For a detailed account of the traditional conception of manly and co-operative virtue see Adkins, 1960.

7 The source of this difficulty stems from the fact that Socrates seems to make three claims which, taken together, are inconsistent: (i) the slave recollects; (ii) the slave does not acquire knowledge; (iii) recollection explains 
acquisition of knowledge. My solution to this puzzle is that while the ultimate aim of recollection is to reach knowledge, recollection of true opinions about eternal and immutable objects, like the truths of mathematics, is a preliminary step towards that final aim. Hence the slave's recollection of true opinions is already an illustration of recollection, since he recollects true opinions about eternal and unchanging objects and understands to some extent reasons why those are true.

8 For the view that sense perception is of no use to recollection in the Meno see Vlastos 1965, 143-67, Gulley 196, 12-13, Gulley 1954, 194-213, Gallop 1975, 115, Buchmann 1936, 68-69, and Scott 2006, 103-105. Vlastos and Gulley argue that the Phaedo's suggestion about the positive role of perception in triggering recollection is an absolutely new aspect of Plato's theory. For criticisms of this position see Bedu-Addo 1983, 228-48, esp. 241-42, H.D. Rankin 1958, 81-86, Dunlop 1975, 51-56. At the opposite end of the spectrum Ross argues that recollection is entirely based on perception (Ross 1951,18).

9 This point illuminates another divergence between my present account and the one developed by Fine. When

Fine equates knowledge with true belief plus an account, she does not insist on the necessity that the object of knowledge be a universal, rather than a particular, and neither does she clarify what counts as adequate account or explanation (Fine 2004, 71-78). Fine's insistence on knowledge being propositional obscures the fact that for Plato it is primarily the disposition of the soul towards understanding rather than the capacity to articulate sentences that count as explanations that makes the whole difference in term of true epistemic achievement. Explanatory accounts fall short of knowledge unless they are anchored in universal intelligible realities.

10 Scholars have often expressed dissatisfaction at the fact that Socrates knows in advance the solution to the mathematical problem, for this a) makes Socrates direct the slave to the answers rather than let him respond freely and b) it weakens the analogy between the two investigations since in the ethical conversation Socrates doesn't know the solution in advance (Bostock 1986, 112, Weiss 2001, 83). But there are good reasons why Plato chooses the mathematical problem whose solution is known in advance. More important than the fact that Socrates knows the answer to the geometrical problem is the fact that Meno and we (the readers) do so, since the illustration is a successful piece only for someone who can appreciate the slave's advance from falsehood to truth. Furthermore, while it is true that the sequence of Socrates' leading mathematical questions is to some extent affected by his knowledge in the field, the fact that Socrates does not know the essence of virtue does not necessarily make his conversation with Meno proceed in a completely random way. For one thing, Socrates has many opinions about virtue; for another, Socrates' elenchus with Meno proceeds through an ordered sequence of questions guided by methodological principles: the priority of knowing the essence over a thing's derivative qualities, the requirements for unity, universality, and necessity of a definition, and the demand that the dialectical partners offer relevant answers.

11 Gulley $(1962,9)$ and Grote $(1867,17-18)$ take Plato's invocation of kinship as referring exclusively to a relation between soul and the Forms, but not also among the Forms themselves. Seeskin leaves the matter undecided as to whether kinship describes a relation between soul and Forms or among Forms themselves,yet he too, just like the other scholars, is inclined to think that it can be only one of them (Seeskin 1987, 109).

12 In the Sophist, for instance, elenchus is used to determine the way megista gene combine with one another (Sophist 250b-253d).

13 For the view that the slave boy's true beliefs are the result of recollection, see also Scott 2006, 98-120, 182-83, Gentzler 1994, 257-95, and Gonzalez 1998, 167-73. That the slave's true opinion results from recollection is not to say that true opinions are always acquired through recollection. True opinions can also be acquired through sense perception and observation, through hearsay or guessing, etc. What makes the slave's case an instance of recollection is not that some of the opinions he asserts happen to be true, but rather the fact that he arrives at them through a process of rational mediation whereby he envisions ideal mathematical objects and relations in order to finally 'see' that the line sought for is the diagonal. Indeed, at the stage actually reached by the slave, his 'sight' of this truth is still feeble and dim. All he can say at this point is that the newly acquired opinion is more acceptable than his previous false ones, since it is more consistent than those were with the host of other beliefs he entertains. But since he cannot give sufficient reasons for its truth, he still falls short of knowledge.

14 This should not be taken to mean that at the end of our dialogue the participants will have attained knowledge of the essence of virtue, but only that, through extended application of the hypothetical method, this kind of accomplishment could eventually occur. In the Meno we witness the method's development, but not also its final and absolute success.

15 I first developed this view in Ionescu 2007, 109-153, esp. 109-111; much of what follows in this section reiterates the reasoning developed there. A few other scholars also argue that the method is applied through to the end of the dialogue. See Kahn 1996, 311-13, Vlastos 1988, 381n60, Benson 2003, 95-126, Benson 2015, 92-182 and Scott 2006, 129ff. While all of the scholars just mentioned agree that the method is applied throughout the remaining part of the dialogue (87d2-100b4), they often disagree over the actual course of Socrates' hypothetical reasoning, as well as over the implications resulting from it.

16 In his latest book, Benson provides an extensive and detailed analysis of the method of hypothesis, and he too recognizes the usefulness of elenchus as integral part of the method of hypothesis (Benson 2015, 154-182). While thus consistent in its major tenet with Benson's position, my present account goes a step beyond his work, insofar as I also identify the reason why the application of the 
hypothetical method yields a confusing and aporetic result in the Meno. The reason for that, I argue, is that midway through the application of the method Socrates seamlessly switches from using virtue, knowledge, and teaching, in the senses he understands these to using the same concepts in Meno's and Anytus' understanding. This switch, I argue, is not due to an intrinsic limitation of the method, nor is it indicative of a grave omission and oblivion on Socrates' part. Rather, it represents a skillful pedagogical device whereby we are taught the importance of preserving the consistency of meanings in the concepts we use throughout our reasoning, and also witness the ignorance of Socrates' interlocutors.

17 Scholars do not generally agree with this view, and argue instead that Socrates is yielding to Meno's request and proceeds to investigate a derivative quality of virtue prior to investigating its essence. See, for instance, Robinson 1953, 114-22, Brown 1967, 63-65, Crombie 1963, 538, Bluck 1961, 23, Rose 1970, 1-8, Sternfeld and Zynskind 1978, 31, 33, 51-52, Meyers 1988, 173-80, Gonzalez 1998, 175-79, and Seeskin 1993, 45-46. For a different view see Bedu-Addo 1984, 1-14 and Benson 2015, 95-102.

18 While most scholars read the remaining part of the dialogue as abandoning Socrates' maxim about the priority of the essence over the derivative qualities of a thing, they often provide divergent interpretations of this situation. Some take it as indication of the discrepancy between Plato's and Socrates' approaches, arguing that Plato, who is more sensitive to our intellectual limitations, has come to disagree with Socrates' unrealistic demands. Most scholars, however, take it as an explanation for the aporetic ending of the dialogue. They argue that the dialogue ends in aporia precisely due to the abandonment of Socrates' maxim. My own view differs from both of these lines of interpretation.

19 Benson perceptively argues that the method of hypothesis in the Meno follows the stages of the hypothetical method in the Phaedo, except they are now taken in reverse order. Thus, according to the Phaedo, Benson writes, '[f]irst, one should examine whether the consequences of the hypothesis agree with one anotherwhatever precisely that means. And second, one should attempt to derive the hypothesis from a yet "higher" hypothesis, and so on until one reaches something "adequate" - again, whatever exactly that means. [...] Meno $87 \mathrm{~d} 2-89 \mathrm{c} 4$ provides an example of the second procedure (an argument to the hypothesis from a 'higher' one), while 89c5-96d4 provides an example of the first (an argument from the hypothesis)' (Benson 2003,115). $20 \mathrm{My}$ understanding of the five stages, first advanced in Ionescu 2007, is consistent with Benson's 2015 account, although he identifies only four stages, where I identify five. The difference in the number of stages stems from the fact that I acknowledge the argument to the conclusion that virtue is not possessed by nature as a distinct stage of the same method's application (Stage 3), whereas Benson doesn't acknowledge it as a separate stage. According to him we have: (1) the proof stage Meno 87b-d, (2) the upward path of confirmation stage (87d2-89c4); (3) the downward path of the confirmation stage (89c5-96d4); (4) a reconsideration of the upward path of the confirmation stage (96d5-100b4). At the end of his investigation Benson declares that most likely the confusing ending is due to a defect in the method's application (Benson 2015, 180), but he offers no suggestions as to what the presumed defect is about. I argue that the reason why we end in a confusing situation resides in a pedagogical strategy of shifting seamlessly from one set of meanings of virtue, teaching and knowledge (Socrates') to another (Meno's and Anytus'), and I identify Stage 3 as the moment when these shifts occur for the first time. In an earlier account Benson identified three stages of the method's application: (a) an argument to the hypothesis, deriving 'virtue is knowledge' from the hypothesis 'virtue is good' $(87 \mathrm{~d} 2-89 \mathrm{c} 4)$ - corresponding to what I identify as stages 1 and 2; (b) an argument from the hypothesis, testing whether virtue is teachable by searching whether there are any teachers of virtue (89c5$96 \mathrm{~d} 4$ ) - corresponding to what I identify as Stage 4; (c) a reconsideration of the argument to the hypothesis: if true opinion is also good and beneficial for action, then virtue need not be knowledge (96d-100b4) - corresponding to what I identify as Stage 5.

21 Exceptions to this are only two passages: (1) 97a698b10, where Socrates draws the distinction between knowledge and true opinion, and (2) 100a1-7, where Socrates envisions the possibility of a genuine teacher of virtue on account of knowledge.

22 The argument proceeds by showing that none of them has been able to impart excellence to their own sons, although (a) they did not lack willingness to do so, since they have been concerned to provide their sons with the best education in other crafts (93e6-8, 94a4-6, 94b4-8, 94c-e2) - horsemanship (93d2-3), wrestling (94c3, c5), javelin-throwing (93d4), music (94b6), athletics (94b5), and (b) their sons' natures seem not to have been deficient, since they have been able to assimilate the instruction received in various crafts (93d). Consequently, the explanation for the statesmen's failure seems to be that virtue is not teachable $(94 \mathrm{e} 2)$. 